\title{
Does Platelet Mass Index Play a Role in Predicting Biochemical Recurrence in Localized Prostate Cancer?
}

\author{
Lokalize Prostat Kanserinde Trombosit Kitle Indeksinin Biyokimyasal Nüksü Öngörmede Yeri \\ Var midır?
}

\author{
(D) Reha Girgin, (D) Önder Çınar, (D) Ersan Bulut, (D) Cemal Ferhat Önal \\ Zonguldak Bülent Ecevit University, Health Practice and Research Center, Clinic of Urology, Zonguldak, Turkiye
}

What's known on the subject? and What does the study add?

The literature data used to predict early recurrence of localized prostate cancer need to be expanded, but studies should be continued.

\begin{abstract}
Objective: The aim of this study is to investigate the association of preoperative platelet mass index (PMI) with tumor pathologic features and postoperative biochemical recurrence in patients undergoing radical prostatectomy due to localized prostate cancer.

Materials and Methods: Data of 141 patients, who underwent radical prostatectomy for localized prostate cancer between April 2004 and April 2017, were retrospectively screened. Patient age, preoperative prostate-specific antigen (PSA) level, platelet count, mean platelet volume and PMI value, neutrophil-lymphocyte ratio (NLR), tumor grade, Gleason score, tumor volume, lymph node involvement, surgical margin positivity and biochemical recurrence at 3 months were all noted. The relationship of preoperative PMI value with age, PSA, pathologic parameters, surgical margin positivity and biochemical recurrence was evaluated.

Results: The mean age of the patients was $61.79 \pm 5.98$ years, the mean PSA value was $9.50 \pm 6.69 \mathrm{ng} / \mathrm{mL}$, mean PMI was $2003.91 \pm 486.69$, and the mean NLR was $2.79 \pm 2.06$. There was no correlation of PMI value with PSA, pathological stage, Gleason score, lymph node involvement, tumor volume, surgical margin positivity, and biochemical recurrence. There was statistically significant negative correlation between PMI and Gleason score.

Conclusion: In our study, we could not demonstrate preoperative PMI as a prognostic factor for early biochemical recurrence in patients undergoing radical prostatectomy for prostate cancer. To achieve a better conclusion that we can generalize, there is a need for prospective studies with larger patient series. Keywords: Platelet mass index, Inflammation, Prostate cancer
\end{abstract}

Öz

Amaç: Bu çalışmanın amacı, lokalize prostat kanseri nedeniyle radikal prostatektomi yapılan hastalarda preoperatif trombosit kitle indeksi (PMI) ile tümörün patolojik özellikleri ve postoperatif biyokimyasal nüks arasındaki ilişkiyi araştırmaktır.

Gereç ve Yöntem: Nisan 2004 ile Nisan 2017 arasında lokalize prostat kanseri nedeniyle radikal prostatektomi yapılan 141 hastanın verileri retrospektif olarak tarandı. Hastaların yaş, preoperatif prostat spesifik antijen (PSA), trombosit sayıSı, ortalama trombosit hacmi ve PMI değerleri, N/L oranı, tümör evresi, Gleason skoru, tümör hacmi, lenf nodu tutulumu, cerrahi sınır pozitifliği ve 3. ayda biyokimyasal nüks olup olmadığı kaydedildi. Ameliyat öncesi PMI değerinin yaş, PSA, patolojik parametreler, cerrahi sınır pozitifliği ve biyokimyasal nüks ile olan ilişkisi incelendi.

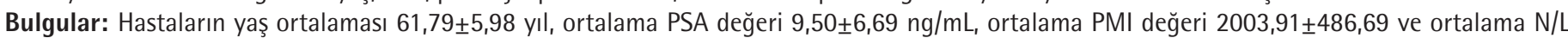
oranı 2,79 2,06 idi. PMI değeri ile PSA, patolojik evre, Gleason skoru, lenf nodu tutulumu, tümör hacmi, cerrahi sınır pozitifliği, biyokimyasal nüks arasında bir korelasyon izlenmedi. PMI ile Gleason skoru arasında istatistiksel olarak anlamlı negatif korelasyon izlendi.

Sonuç: Çalışmamızda prostat kanseri nedeniyle radikal prostatektomi uygulanmış hastalarda ameliyat öncesi PMI değerini, erken biyokimyasal nüks için prognostik bir faktör olarak gösteremedik. Genelleme yapabileceğimiz daha iyi bir sonuç elde etmek için, daha geniş hasta serileri ile prospektif olarak tasarlanmış çalışmalara ihtiyaç vardır.

Anahtar Kelimeler: Trombosit kitle indeksi, Enflamasyon, Prostat kanseri

Correspondence: Reha Girgin MD, Zonguldak Bülent Ecevit University, Health Practice and Research Center, Clinic of Urology, Zonguldak, Turkiye E-mail: mujdereha@hotmail.com ORCID-ID: orcid.org/0000-0003-1132-8629

Received: 01.03.2018 Accepted: 04.06.2018

Cite this article as: Girgin R, Çınar Ö, Bulut E, Önal CF. Does Platelet Mass Index Play a Role in Predicting Biochemical Recurrence in Localized Prostate Cancer? J Urol Surg 2018;5(3):164-169.

๑Copyright 2018 by the Association of Urological Surgery / Journal of Urological Surgery published by Galenos Publishing House. 


\section{Introduction}

Although prostate cancer is now accepted as an important cause of male deaths, the mystery over the behavior of cancer cells is still ongoing. Prostate-specific antigen (PSA) screening can be used in the diagnosis of early-stage prostate cancer, but the pathological features of cases undergoing radical surgery continue to be questioned. For this reason, there is still a need to update the information on prostate cancer. The relationship between cancer formation and inflammation has become a very interesting subject nowadays and the evidence about the link between these two conditions is increasing day by day. It has been shown that increased angiogenesis as a result of inflammation caused by infection, autoimmunity, chronic irritation, and tumor and resulting from treatments, contributes to carcinogenesis (1). The relationship between tumor survival and inflammation has been tried to be shown using neutrophil-lymphocyte ratio (NLR) in many cancer types. It is known that platelets play an important role not only in achieving hemostasis but also in inflammatory reactions and in immunological responses $(2,3,4,5)$. Mean platelet volume (MPV) has been previously reported to be a marker of platelet activation, but, recently, platelet mass index (PMI) calculated by multiplying platelet count by MPV was claimed to be a better parameter of inflammation than MPV in a study $(6,7)$.

In this retrospective study, we aimed to investigate the association of preoperative PMI with tumor pathologic features and postoperative biochemical recurrence in patients undergoing radical prostatectomy due to localized prostate cancer.

\section{Materials and Methods}

Data of patients, who underwent radical prostatectomy for localized prostate cancer at Zonguldak Bülent Ecevit University, Health Practice and Research Center, Clinic of Urology between April 2004 and April 2017 by four expert surgeons in urooncology, were retrospectively screened following the approval of Bülent Ecevit University Local Ethics Committee (protocol number: 2018-23-17/01). Using hospital records, patients' age, preoperative PSA, platelet count, MPV and PMI value, NLR, tumor grade, Gleason score, tumor volume, lymph node involvement, surgical margin positivity, and biochemical recurrence at 3 months were analyzed. A total of 141 patients with written consent and at least 6 months of follow-up were included in the study. PMI value was examined in relation to age, PSA, pathologic parameters, surgical margin positivity and biochemical recurrence. Biochemical recurrence was accepted when an additional treatment started at the third month control with an increase of PSA value or if there was a persistent increase in PSA value at the $6^{\text {th }}$ month control.

\section{Statistical Analysis}

Mean, standard deviation, median lowest, highest, frequency and ratio values were used in the descriptive statistics of the data. The distribution of the variables was measured by the Kolmogorov-Smirnov test. The Kruskal-Wallis test and the Mann-Whitney $\mathrm{U}$ test were used in the analysis of quantitative independent data. In correlation analysis, the Spearman correlation coefficient was used. SPSS 18.0 program was used for statistical analysis.

\section{Results}

The mean age of the patients was $61.79 \pm 5.98$ years, the mean PSA value was $9.50 \pm 6.69 \mathrm{ng} / \mathrm{mL}$, the mean PMI was $2003.91 \pm 486.69$, and mean NLR was $2.79 \pm 2.06$. The preoperative data of the patients are summarized in Table 1. The mean tumor volume was $9.20 \pm 8.42 \mathrm{~cm}^{3}$. Four (2.8\%) patients had lymph node involvement, while $66(47.6 \%)$ patients had positive surgical margin; 25 (17.5\%) patients had biochemical recurrence at the third month control. The distribution of patients according to preoperative PSA levels and pathologic variables is shown in Table 2. The relationship between surgical margin involvement and histopathological findings is shown in Table 3. There was no correlation of PMI value with PSA, pathological stage, Gleason score, lymph node involvement, tumor volume, surgical margin positivity, and biochemical recurrence (Table 4). The correlation of NLR with PSA, pathological stage, Gleason score, lymph node involvement, tumor volume, surgical margin positivity, and biochemical recurrence is shown in Table 5. NLR was statistically significantly lower in lymph node-positive patients. Analysis of correlation between NLR and age, PSA, Gleason score and tumor volume and between PMI and age, PSA, Gleason score and tumor volume are shown in Table 6 . There was a statistically significant negative correlation between PMI and Gleason score.

Table 1. Preoperative data of the patients

\begin{tabular}{llll}
\hline & Min & Max & Mean \pm SD \\
\hline Age (year) & 42 & 74 & $61.79 \pm 5.98$ \\
Total PSA $(\mathrm{ng} / \mathrm{mL})$ & 2.41 & 36.72 & $9.50 \pm 6.69$ \\
Platelet count $(\mathrm{K} / \mu \mathrm{L})$ & 130 & 461 & $243.02 \pm 66.13$ \\
MPV $(\mathrm{fL})$ & 6.7 & 11.5 & $8.3 \pm 0.93$ \\
PMI & 962 & 3558.3 & $2003.91 \pm 486.69$ \\
Neutrophil count $(\mathrm{K} / \mu \mathrm{L})$ & 0.6 & 17.2 & $4.96 \pm 2.25$ \\
Lymphocyte count $(\mathrm{K} / \mu \mathrm{L})$ & 0.5 & 4.6 & $2.07 \pm 0.72$ \\
NLR & 0.31 & 17.20 & $2.79 \pm 2.06$ \\
Tumor volume $\left(\mathrm{cm}^{3}\right)$ & 0.12 & 38.5 & $9.20 \pm 8.42$ \\
\hline
\end{tabular}

PSA: Prostate-specific antigen, MPV: Mean platelet volume, PMI: Platelet mass index, NLR: Neutrophil-lymphocyte ratio, Min: Minimum, Max: Maximum, SD: Standard deviation 
Table 2. The distribution of patients according to preoperative prostate-specific antigen levels and pathologic variables

\begin{tabular}{|c|c|c|c|}
\hline & & $\mathbf{n}$ & $\%$ \\
\hline \multicolumn{4}{|l|}{ PSA (ng/mL) } \\
\hline & $0-4$ & 4 & 2.8 \\
\hline & $4-10$ & 95 & 66.4 \\
\hline & $10-20$ & 30 & 21.0 \\
\hline & $20<$ & 12 & 8.5 \\
\hline \multicolumn{4}{|l|}{ Clinical stage } \\
\hline & $\mathrm{T} 2 \mathrm{a}$ & 21 & 14.7 \\
\hline & $\mathrm{T} 2 \mathrm{~b}$ & 11 & 7.7 \\
\hline & $\mathrm{T} 2 \mathrm{c}$ & 42 & 29.4 \\
\hline & T3a & 55 & 38.5 \\
\hline & $\mathrm{T} 3 \mathrm{~b}$ & 12 & 8.4 \\
\hline \multicolumn{4}{|l|}{ Surgical margin } \\
\hline & Negative & 75 & 52.4 \\
\hline & Apex & 29 & 20.3 \\
\hline & Basal & 12 & 8.4 \\
\hline & Multifocal & 25 & 17.5 \\
\hline \multicolumn{4}{|l|}{ Lymphovascular invasion } \\
\hline & Negative & 123 & 86.0 \\
\hline & Positive & 17 & 11.9 \\
\hline \multicolumn{4}{|l|}{ Perineural invasion } \\
\hline & Negative & 51 & 35.7 \\
\hline & Positive & 90 & 62.9 \\
\hline \multicolumn{4}{|l|}{ Seminal vesicle invasion } \\
\hline & Negative & 128 & 89.5 \\
\hline & Positive & 13 & 9.1 \\
\hline \multicolumn{4}{|l|}{ Lymph node invasion } \\
\hline & Negative & 137 & 95.8 \\
\hline & Positive & 4 & 2.8 \\
\hline \multicolumn{4}{|l|}{$\begin{array}{l}\text { Third month biochemical } \\
\text { recurrence }\end{array}$} \\
\hline & No & 116 & 81.1 \\
\hline & Yes & 25 & 17.5 \\
\hline
\end{tabular}

\section{Discussion}

It is known that the development of tumor cells in our body activates an inflammatory response. Systemic inflammation also suppresses the anti-tumor immune system, thus facilitating cancer progression and metastasis $(8,9,10,11,12,13)$. Previously, biomarkers of inflammation, such as NLR, platelet-lymphocyte ratio and C-reactive protein, have been shown to be valuable prognostic factors in many cancers $(8,10,11,12,14,15,16,17)$. During the inflammatory process, many mediators that activate thrombocytes are released. Platelets secrete various growth factors that support angiogenesis, cell proliferation and metastasis $(15,16,17,18,19)$. Tumor-associated thrombocyte aggregation forms a barrier against T-cells by forming a protective shield around the tumor cells $(20,21)$.

While localized prostate cancer treatment and follow-up schemes are created, many biochemical and pathological data are benefited from. Prostate cancer may show differences between treatment strategies when cases become resistant to castration. Thus, the idea of using simple blood tests to guide the experts is available for a long time. NLR is the most studied parameter for this purpose. However, in the literature, we have not seen any study evaluating such a relationship with PMI in prostate cancer.

In our study comparing the NLR with preoperative PSA value, pathologic data and the presence of biochemical recurrence in patients with localized prostate cancer undergoing radical prostatectomy, NLR was lower in lymph node-positive patients and it was statistically significant. Unlike our work, a significant correlation was found between high NLR and lymph node positivity in a study with 1688 patients performed by Zhang et al. (22). However, in their study with 217 cases, Kwon et al. (23) found a positive relationship only between NLR and Gleason score. On the other hand, we did not observe a relationship with other parameters.

PMI is a biomarker that has recently attracted the attention of researchers. In the first study about PMI, it has been reported that unnecessary platelet transfusions in neonatal intensive care units could be prevented $(24,25,26,27)$. There is an inverse

Table 3. Distribution of histopathological findings with surgical margin involvement

\begin{tabular}{|c|c|c|c|c|c|c|}
\hline & & \multicolumn{4}{|c|}{ Surgical margin involvement $\mathrm{n}(\%)^{*}$} & \multirow[b]{2}{*}{$\mathbf{p}$} \\
\hline & & Non & Apex & Basal & Multifocal & \\
\hline \multirow[t]{3}{*}{ Gleason score } & $5-6$ & $51(68.0)$ & $13(17.3)$ & $5(6.7)$ & $6(8.0)$ & 0.003 \\
\hline & 7 & $22(40.0)$ & $13(23.6)$ & $6(10.9)$ & $14(25.6)$ & \\
\hline & 8 and above & $2(18.2)$ & $3(27.3)$ & $1(9.1)$ & $5(45.5)$ & \\
\hline
\end{tabular}

${ }^{*}$ Percentages are given in parentheses, $p<0.05$ 
Table 4. Correlation between platelet mass index value and biochemical and pathological variables

\begin{tabular}{|c|c|c|c|c|c|}
\hline \multicolumn{6}{|l|}{ PMI } \\
\hline & & Min-max & Median & Mean \pm SD & $\mathbf{p}^{*}$ \\
\hline \multirow[t]{4}{*}{ PSA (ng/mL) } & $0-4$ & $1579-2456$ & 1789 & $1903 \pm 384$ & \multirow{4}{*}{0.588} \\
\hline & $4-10$ & $962-3558$ & 1923 & $1989 \pm 502$ & \\
\hline & $10-20$ & $1340-2978$ & 1899 & $1985 \pm 412$ & \\
\hline & $20<$ & $1235-3091$ & 2097 & $2202 \pm 571$ & \\
\hline \multirow[t]{2}{*}{ Clinical stage } & $\mathrm{T} 2$ & $1047-3273$ & 1938 & $2017 \pm 442$ & \multirow{2}{*}{0.548} \\
\hline & T3 & $962-3558$ & 1913 & $1990 \pm 534$ & \\
\hline \multirow[t]{3}{*}{ Gleason } & $5-6$ & $962-3558$ & 2049 & $2077 \pm 497$ & \multirow{3}{*}{0.157} \\
\hline & 7 & $1066-3091$ & 1847 & $1922 \pm 476$ & \\
\hline & $8<$ & $1322-2468$ & 2009 & $1915 \pm 423$ & \\
\hline \multirow[t]{2}{*}{ Tumor volume $\left(\mathrm{cm}^{3}\right)$} & $\leq 5$ & $962-3273$ & 1962 & $2013 \pm 459$ & \multirow{2}{*}{0.533} \\
\hline & $5<$ & $1066-3558$ & 1908 & $2007 \pm 509$ & \\
\hline \multirow[t]{2}{*}{ Surgical margin } & $(-)$ & $1047-3273$ & 1938 & $2003 \pm 432$ & \multirow{2}{*}{0.968} \\
\hline & $(+)$ & $962-3558$ & 1877 & $2005 \pm 546$ & \\
\hline \multirow[t]{2}{*}{ Lymph node invasion } & $(-)$ & $962-3558$ & 1932 & $2009 \pm 491$ & \multirow{2}{*}{0.164} \\
\hline & $(+)$ & $1448-1883$ & 1742 & $1704 \pm 186$ & \\
\hline \multirow[t]{2}{*}{ Biochemical recurrence } & $(-)$ & $962-3558$ & 1918 & $2005 \pm 492$ & \multirow{2}{*}{0.929} \\
\hline & $(+)$ & $1235-3091$ & 1998 & $2032 \pm 468$ & \\
\hline
\end{tabular}

PSA: Prostate-specific antigen, PMI: Platelet mass index, Min: Minimum, Max: Maximum, SD: Standard deviation ${ }^{*} p<0.05$

Table 5. Correlation between neutrophil-lymphocyte ratio and biochemical and pathological variables

\begin{tabular}{|c|c|c|c|c|c|}
\hline NLR & & & & & \\
\hline & & Min-max & Median & Mean \pm SD & $\mathbf{p}^{*}$ \\
\hline \multirow[t]{4}{*}{ PSA (ng/mL) } & $0-4$ & $1.6-3.5$ & 2.04 & $2.31 \pm 0.82$ & \multirow{4}{*}{0.920} \\
\hline & $4-10$ & $0.32-17.2$ & 2.25 & $2.87 \pm 2.33$ & \\
\hline & $10-20$ & $0.87-7.22$ & 2.09 & $2.61 \pm 1.49$ & \\
\hline & $20<$ & $1.09-5.07$ & 2.54 & $2.88 \pm 1.37$ & \\
\hline \multirow[t]{2}{*}{ Clinical stage } & T2 & $0.32-9.6$ & 2.43 & $2.89 \pm 1.98$ & \multirow{2}{*}{0.444} \\
\hline & T3 & $0.91-17.2$ & 2.07 & $2.7 \pm 2.17$ & \\
\hline \multirow[t]{3}{*}{ Gleason } & $5-6$ & $0.88-9.6$ & 2.41 & $2.81 \pm 1.66$ & \multirow{3}{*}{0.433} \\
\hline & 7 & $0.32-17.2$ & 2 & $2.88 \pm 2.66$ & \\
\hline & $8<$ & $1-4.18$ & 2.09 & $2.31 \pm 0.95$ & \\
\hline \multirow[t]{2}{*}{ Tumor volume $\left(\mathrm{cm}^{3}\right)$} & $\leq 5$ & $0.91-9.6$ & 2.17 & $2.76 \pm 1.71$ & \multirow{2}{*}{0.835} \\
\hline & $5<$ & $0.32-17.2$ & 2.22 & $3.03 \pm 2.3$ & \\
\hline \multirow[t]{2}{*}{ Surgical margin } & $(-)$ & $0.78-9.6$ & 2.33 & $2.73 \pm 1.73$ & \multirow{2}{*}{0.882} \\
\hline & $(+)$ & $0.32-17.2$ & 2.1 & $2.87 \pm 2.41$ & \\
\hline \multirow[t]{2}{*}{ Lymph node invasion } & $(-)$ & $0.32-17.2$ & 2.23 & $2.83 \pm 2.08$ & \multirow{2}{*}{0.02} \\
\hline & $(+)$ & $1-1.96$ & 1.24 & $1.36 \pm 0.44$ & \\
\hline \multirow[t]{2}{*}{ Biochemical recurrence } & $(-)$ & $0.32-17.2$ & 2.2 & $2.9 \pm 2.18$ & \multirow{2}{*}{0.688} \\
\hline & $(+)$ & $1.09-6.56$ & 2.11 & $2.84 \pm 1.48$ & \\
\hline
\end{tabular}


Table 6. Analysis of correlation between neutrophillymphocyte ratio and platelet mass index value

\begin{tabular}{llllll}
\hline & & Age & PSA & Gleason & Tumor volume \\
\hline \multirow{2}{*}{ NLR } & $r$ & -0.003 & 0.036 & -0.99 & -0.002 \\
& $p$ & 0.972 & 0.674 & 0.242 & 0.985 \\
\hline & & Age & PSA & Gleason & Tumor volume \\
\hline \multirow{2}{*}{ PMI } & $r$ & -0.119 & 0.005 & -0.16 & -0.037 \\
& $p$ & 0.158 & 0.95 & 0.049 & 0.667 \\
\hline
\end{tabular}

PSA: Prostate-specific antigen, NLR: Neutrophil-lymphocyte ratio, PMI: Platelet mass index

Spearman correlation coefficient

relationship between platelet count and platelet volume in order to keep PMI stable, and therefore platelet activity at a constant value. Apart from PMI value, high MPV value and larger platelet diameter were found to be associated with increased platelet activity (28).

It is seen in the literature that MPV has different prognostic significance in different cancers. However, how MPV values affect prognosis remains to be discussed. High MPV value is significant in breast and hepatocellular carcinomas, but it gains significance when decreasing in lung cancer $(29,30,31,32,33)$. It is not possible to reach a definite result with MPV today. Elevation in platelet count was found to be associated with metastasis development and poor prognosis in some solid cancers $(34,35)$. This is being explained by the overproduction of megakaryocyte colony-stimulating cytokines (36). On the other hand, it has been also claimed that platelets act as a protective shield against circulating tumor cells (37). Takeuchi et al. $(38,39)$ showed that the higher the platelet counts and plateletlymphocyte ratio the poorer the prognosis of breast cancer. The prognostic value of increase in the number of platelets in renal cell carcinoma cases has also been investigated, but the results were different from each other (36).

In this pioneer study, a negative correlation between PMI and Gleason score was found which was to be statistically significant. We assume that the low number of patients may be misleading. We did not observe a statistically significant difference between PMI values and biochemical recurrence among patients.

\section{Study Limitations}

There were some limitations in this study. First, the retrospective nature of the study makes it difficult to obtain generalizable results. The lack of long-term follow-up results of patients was the other limitation of this study. The low number of patients treated at a single institution also weakens the power of influence of the study.

\section{Conclusion}

Our study demonstrates that preoperative PMI is not a prognostic factor for early biochemical recurrence in patients undergoing radical prostatectomy for prostate cancer. When the literature is examined, it is emphasized that platelet count and platelet volume may be prognostic factors in some advanced cancers. To achieve the same result for PMI values in prostate cancer, there is a need for prospective studies with larger patient series.

\section{Ethics}

Ethics Committee Approval: This study was approved by Bülent Ecevit University Local Ethics Committee (protocol number: 2018-23-17/01).

Informed Consent: Written consent was taken from all patients. Peer-review: Externally peer-reviewed.

\section{Authorship Contributions}

Surgical and Medical Practices: R.G., E.B., Ö.Ç., Concept: R.G., Design: R.G., Data Collection or Processing: C.F.Ö., E.B., Analysis or Interpretation: R.G., E.B., Ö.Ç., Literature Search: C.F.Ö., Writing: R.G.

Conflict of Interest: No conflict of interest was declared by the authors.

Financial Disclosure: The authors declared that this study received no financial support.

\section{References}

1. Grivennikov SI, Greten FR, Karin M. Immunity, Inflammation, and Cancer. Cell 2010;140:883-899.

2. Nording HM, Seizer $P$, Langer HF. Platelets in inflammation and atherogenesis. Front Immunol 2015;6:98.

3. Kaser A, Brandacher G, Steurer W, Kaser S, Offner FA, Zoller H, Theurl I, Widder W, Molnar C, Ludwiczek O, Atkins MB, Mier JW, Tilg H. Interleukin-6 stimulates thrombopoiesis through thrombopoietin: role in inflammatory thrombocytosis. Blood 2001;98:2720-2725.

4. Katoh N. Platelets as versatile regulators of cutaneous inflammation. J Dermatol Sci 2009;53:89-95.

5. Boehncke WH, Boehncke S, Tobin AM, Kirby B. The 'psoriatic march': a concept of how severe psoriasis may drive cardiovascular comorbidity. Exp Dermatol 2011;20:303-307.

6. Okur N, Buyuktiryaki M, Uras N, Oncel MY, Ertekin O, Canpolat FE, Oguz SS. Platelet mass index in very preterm infants: can it be used as a parameter for neonatal morbidities? J Matern Fetal Neonatal Med 2016;29:3218-3222.

7. Korkmaz L, Baştuğ O, Ozdemir A, Korkut S, Karaca C, Akin MA, Gunes T, Kurtoglu S, Ozturk MA. The efficacy of propranolol in retinopathy of prematurity and its correlation with the platelet mass index. Curr Eye Res 2017;42:88-97.

8. Huang XZ, Chen WJ, Zhang $X$, Wu CC, Zhang CY, Sun SS, Wu J. An Elevated Platelet-to-Lymphocyte Ratio Predicts Poor Prognosis and Clinicopathological Characteristics in Patients with Colorectal Cancer: A Meta-Analysis. Dis Markers 2017;2017:1053125. 
9. Wang W, Bian C, Xia D, He JX, Hai P, Zhao R, Wang YY. Combining Carcinoembryonic Antigen and Platelet to Lymphocyte Ratio to Predict Brain Metastasis of Resected Lung Adenocarcinoma Patients. Biomed Res Int 2017;2017:8076384.

10. Song W, Tian C, Wang K, Zhang RJ, Zou SB. Preoperative platelet lymphocyte ratio as independent predictors of prognosis in pancreatic cancer: $A$ systematic review and meta-analysis. PloS One 2017;12:e0178762.

11. Shirai $Y$, Shiba H, Sakamoto $T$, Horiuchi $T$, Haruki $K$, Fujiwara $Y$, Futagawa Y, Ohashi T, Yanaga K. Preoperative platelet to lymphocyte ratio predicts outcome of patients with pancreatic ductal adenocarcinoma after pancreatic resection. Surgery 2015;158:360-365.

12. Yang $H J$, Jiang $J H$, Liu $Q A$, Zhou CM, Du YF, Wu T, Chen NZ, Xiang BD. Preoperative plateletto-lymphocyte ratio is a valuable prognostic biomarker in patients with hepatocellular carcinoma undergoing curative liver resection. Tumour Biol 2017;39:1010428317707375.

13. Koh $\mathrm{CH}$, Bhoo-Pathy $\mathrm{N}, \mathrm{Ng} \mathrm{KL}$, Jabir $\mathrm{RS}$, Tan $\mathrm{GH}$, See $\mathrm{MH}$, Jamaris $\mathrm{S}$, Taib NA. Utility of pretreatment neutrophil-lymphocyte ratio and plateletlymphocyte ratio as prognostic factors in breast cancer. $\mathrm{Br} \mathrm{J}$ Cancer 2015;113:150-158.

14. Fuentes HE, Oramas DM, Paz LH, Wang Y, Andrade XA, Tafur AJ. Venous Thromboembolism Is an Independent Predictor of Mortality Among Patients with Gastric Cancer. J Gastrointest Cancer 2017.

15. Kwon HC, Kim SH, Oh SY, Lee S, Lee JH, Choi HJ, Park KJ, Roh MS, Kim SG, Kim HJ, Lee JH. Clinical significance of preoperative neutrophil-lymphocyte versus plateletlymphocyte ratio in patients with operable colorectal cancer. Biomarkers 2012;17:216-222.

16. Smith RA, Bosonnet L, Raraty M, Sutton R, Neoptolemos JP, Campbell $F$, Ghaneh P. Preoperative platelet-lymphocyte ratio is an independent significant prognostic marker in resected pancreatic ductal adenocarcinoma. Am J Surg 2009;197:466-472.

17. Baranyai Z, Krzystanek $M$, Jósa $V$, Dede $K$, Agoston $E_{1}$ Szász AM, Sinkó $D$, Szarvas V, Salamon F, Eklund AC, Szállási Z, Jakab F. The comparison of thrombocytosis and platelet-lymphocyte ratio as potential prognostic markers in colorectal cancer. Thromb Haemost 2014;111:483-490.

18. Lai Q, Castro Santa E, Rico Juri JM, Pinheiro RS, Lerut J. Neutrophil and platelet-to-lymphocyte ratio as new predictors of dropout and recurrence after liver transplantation for hepatocellular cancer. Transpl Int 2014;27:3241.

19. McMillan DC. Systemic inflammation, nutritional status and survival in patients with cancer. Curr Opin Clin Nutr Metab Care 2009;12:223-226.

20. Suzuki K, Aiura K, Ueda M, Kitajima M. The influence of platelets on the promotion of invasion by tumor cells and inhibition by antiplatelet agents. Pancreas 2004;29:132-140.

21. Palumbo JS, Talmage KE, Massari JV, La Jeunesse CM, Flick MJ, Kombrinck KW, Jirousková M, Degen JL. Platelets and fibrin(ogen) increase metastatic potential by impeding natural killer cell-mediated elimination of tumor cells. Blood 2005;105:178-185.

22. Zhang GM, Zhu Y, Ma XC, Qin XJ, Wan FN, Dai B, Sun $\sqcup$, Ye DW. Pretreatment Neutrophil-toLymphocyte Ratio: A Predictor of Advanced Prostate Cancer and Biochemical Recurrence in Patients Receiving Radical Prostatectomy. Medicine (Baltimore) 2015;94:e1473.

23. Kwon YS, Han CS, Yu JW, Kim S, Modi P, Davis R, Park JH, Lee $P$, Ha YS, Kim WJ, Kim IY. Neutrophil and Lymphocyte Counts as Clinical Markers for Stratifying Low-Risk Prostate Cancer. Clin Genitourin Cancer 2016;14:1-8.
24. Zisk JL, Mackley A, Clearly G, Chang E, Christensen RD, Paul DA. Transfusing neonates based on platelet count vs. platelet mass: a randomized feasibilitypilot study. Platelets 2014;25:513-516.

25. Kahvecioglu D, Erdeve O, Alan S, Cakir U, Yildiz D, Atasay B, Arsan S. The impact of evaluating platelet transfusion need by platelet mass index on reducing the unnecessary transfusions in newborns. J Matern Fetal Neonatal Med 2014;27:1787-1789.

26. Gerday E, Baer VL, Lambert DK, Paul DA, Sola-Visner MC, Pysher TJ, Christensen RD. Testing platelet mass versus platelet count to guide platelet transfusions in the neonatal intensive care unit. Transfusion 2009;49:20342039.

27. Christensen RD. Platelet transfusion in the neonatal intensive care unit: benefits, risks, alternatives. Neonatology 2011;100:311-318.

28. Kamath S, Blann AD, Lip GY. Platelet activation: assessment and quantification. Eur Heart J 2001;22:1561-1571.

29. Zhang F, Chen Z, Wang $P, H u X$, Gao $Y$, He J. Combination of platelet count and mean platelet volume (COP-MPV) predicts postoperative prognosis in both resectable early and advanced stage esophageal squamous cell cancer patients. Tumour Biol 2016;37:9323-9331.

30. Gu M, Zhai Z, Huang L, Zheng W, Zhou Y, Zhu R, Shen F, Yuan C. Pre-treatment mean platelet volume associates with worse clinicopathologic features and prognosis with invasive breast cancer. Breast Cancer 2016;23:752-760.

31. Cho SY, Yang JJ, You E, Kim BH, Shim J, Lee HJ, Lee WI, Suh JT, Park TS. Mean platelet volume/ platelet count ratio in hepatocellular carcinoma. Platelets 2013:24:375-377.

32. Inagaki N, Kibata K, Tamaki T, Shimizu T, Nomura S. Prognostic impact of the mean platelet volume/ platelet count ratio in terms of survival in advanced non-small cell lung cancer. Lung Cancer 2014;83:97-101.

33. Kumagai $S$, Tokuno J, Ueda $Y$, Marumo $S$, Shoji T, Nishimura T, Fukui M, Huang CL. Prognostic significance of preoperative mean platelet volume in resected non-small-cell lung cancer. Mol Clin Oncol 2015;3:197-201.

34. Mezouar S, Frere C, Darbousset R, Mege D, Crescence L, Dignat-George $F$, Panicot-Dubois L, Dubois C. Role of platelets in cancer and cancerassociated thrombosis: experimental and clinical evidences. Thromb Res 2016;139:65-76.

35. Meikle CK, Kelly CA, Garg P, Wuescher LM, Ali RA, Worth RG. Cancer and thrombosis: the platelet perspective. Front Cell Dev Biol 2016;4:147.

36. Ha YS, Chung JW, Chun SY, Choi SH, Lee JN, Kim BS, Kim HT, Kim TH, Byun SS, Hwang EC, Kang SH, Hong SH, Chung J, Kwak C, Kim YJ, Kwon TG; KORCC study group. Impact of preoperative thrombocytosis on prognosis after surgical treatment in pathological T1 and T2 renal cell carcinoma: results of a multi-institutional comprehensive study. Oncotarget 2017;8:6444964458.

37. Nieswandt $B$, Hafner M, Echtenacher B, Mannel DN. Lysis of tumor cells by natural killer cells in mice is impeded by platelets. Cancer Res 1999;59:12951300.

38. Takeuchi H, Fukuyama S, Kubo N, Hiroshige S, Kawanaka H, Yoshikawa $Y$ Yano T. The prognostic significance of the preoperative platelet-lymphocyte ratio in Japanese patients with localized breast cancer. Adv Breast Cancer Res 2016;5:49-57.

39. Takeuchi $H$, Kawanaka $H$, Fukuyama $S$, Kubo N, Hiroshige $S$, Yano $T$. Comparison of the prognostic values of preoperative inflammation-based parameters in patients with breast cancer. PLoS One 2017;12:e0177137. 